IOSR Journal of Pharmacy

ISSN: 2250-3013, www.iosrphr.org

\||| Volume 2 Issue 5 \||| Sep-Oct. 2012 || | PP.01-04

\title{
Nicotine induced oxidative damage in rat lymphocytes - an Invitrostudy
}

\author{
Karmakar A ${ }^{1}$, Adhikari $\mathrm{S}^{2}$
}

\begin{abstract}
Nicotine is a potent toxic substance of cigarette smoke that has been shown to influence alterations in immunity and various metabolic processes. In this study, we evaluated the effect of nicotine toxicity on lymphocyte, a critical cell of cellular immunity using different doses at different durations. Lymphocytes were isolated by centrifugation in the density gradient from the whole blood of rats. Theywere spread over the culture media, treated with different doses of nicotine (10, 100, 100mM) for different durations (6 and 12 hours) in comparison with the control. After the experimental period, lymphocytes morphology, viability, superoxide radical concentration, malondialdehyde content, superoxide dismutase levels and DNA fragmentation were measured. The findings were analysed using one way ANOVA. The marked morphological changes in lymphocytes were observed along with decrease in presence of nicotine in a dose and duration dependent manner. There was also significant decreased in the cell viability and antioxidant enzymes, level of lipid peroxidation (LP) and DNA fragmentation was increased in nicotine treated lymphocytes compared with the control. Thus, above findings indicate that nicotine treatment at different dose and duration induces cellular damage by changing cell membrane integrity.
\end{abstract}

Kewwords-Antioxidant Activity, Lymphocytes, Nicotine, Oxidative stress.

\section{INTRODUCTION}

The main role of immune system is to identify and remove invading pathogens, and other harmful agents that affect our body. The lymphocytes are important component of the immune system and will be exposed to many toxins. Cigarette smoke has thousands of chemicals, many of which are known carcinogens including nicotine. Nicotine, a potent toxic substance derived from solanacea group of plants has been shown to influence alterations in immunity and various metabolic processes [1, 2]. In this study, we evaluated the effect of nicotine on cellular toxicity of lymphocytes in different doses and durations.

\section{MATERIALS AND METHODS}

Male Wistar rats (150-200g) were used in the study, maintained in accordance with CPCSEA guidelines. The study was done after getting approval from ethical committee. The whole blood was collected from subclavian vein of rats and lymphocytes were isolated.

A. Isolation of Lymphocytes

The collected heparinised blood was diluted with phosphate-buffered saline (pH 7.0) in equal ratio and then layered on the density gradient (Histopaque1077, Sigma Chemical Co.) in 1:2 ratios. The white milky layer of mononuclear cells, i.e., lymphocytes was carefully removed after centrifugation at $500 \mathrm{~g}$ for $20 \mathrm{~min}$. The layer was then washed twice with the same buffer and centrifuged at $3000 \mathrm{~g}$ for $10 \mathrm{~min}$ to get the required pellet of lymphocytes. [3]

B. Experimental Design

The lymphocytes were divided into eight groups, including control(C) and nicotine treated groups (NTG); group I (10mM), II (100mM) and III $(1000 \mathrm{mM})$. Each groups wereof two types i.e. 'A' and 'B', based on the duration of exposures i.e. $6 \mathrm{hrs}$ and $12 \mathrm{hrs}$ respectively. The concentration of cells was $2 \times 10^{6} / \mathrm{ml}$ of culture media. The samples were cultured at $37{ }^{\circ} \mathrm{C}$ with $5 \% \mathrm{CO}_{2}$ in a $\mathrm{CO}_{2}$ incubator, containing RPMI 1640 with $10 \%$ fetal bovine serum (Sigma), $50 \mu \mathrm{g} / \mathrm{ml}$ gentamycin, $50 \mu \mathrm{g} / \mathrm{ml}$ penicillin and $50 \mu \mathrm{g} / \mathrm{ml}$ streptomycin. Then the cells were collected from the petridis and spin in a cold centrifuge at $4^{\circ} \mathrm{C}$ of 2400 r.p.m. After discarding the supernatant, cell pellets were lysed with hypotonic cell lysis buffer (10mm TRIS, 1mM WDTA and Triton X-100, $\mathrm{pH}-8.0$ ) and stored at $-80^{\circ} \mathrm{C}$ for biochemical estimation. Intact cells were used for morphological, viability and superoxide production analysis. 


\section{Parameters Studied}

\section{Determination of Lymphocyte Morphology usingGimsa Staining}

First, cell suspension of lymphocytes were spread in glass slide and dried. Then Gimsa stain was added to it and after 6 minutes, double volume of distilled water was added to the slide and kept for 2 min. Later the slide was kept under running tap water for 8 minutes and dried to observe under oil immersion microscope.

\section{Cell Viability using trypan blue exclusion method}

Here, $10 \mu \mathrm{l}$ of cell suspension was mixed with $10 \mu \mathrm{l}$ of trypan blue and charged into the Neubauer's chamber. The viable lymphocytes did not take up the colour and seen like pearls under light microscope. The count was done in each corner of Neubauer's chamber. Viable and non-viable cells are counted and calculated as percentage of cell viability. [4]

\section{Superoxide anion $\left(\mathrm{O}_{2}^{-\bullet}\right.$ ) production by Cytochrome C reduction assay}

In this method, $250 \mu 1$ of washed cell suspension and $250 \mu 1$ of $0.2 \mathrm{mM}$ ferricytochrome c were mixed in a cuvette. The cells were activated by the addition of $2 \mu 1$ phorbol 12 -myristate 13 -acetate $\left(1 \times 10^{-8} \mathrm{M}\right)$. Optical density was measured at $550 \mathrm{~nm}$ in a spectrophotometer fitted with a thermostated cuvette holder set at $37^{\circ} \mathrm{C}$. The specificity of ferricytochrome $\mathrm{c}$ reduction was checked in all experiments by the addition of $15 \mu \mathrm{g}$ superoxide dismutase to a control tube containing the reaction mixture. $[5,6,7]$

\section{Lipid peroxidation by Thiobarbituric acid test}

In this test, a product of lipid peroxidation, malondialdehyde was determined. Here, $0.1 \mathrm{ml}$ of lymphocyte suspension was added to the test tube containing $0.2 \mathrm{ml}$ of $8.1 \%$ SDS, $1.5 \mathrm{ml}$ of $20 \%$ acetic acid solution, $\mathrm{pH} 3.5$, and $1.5 \mathrm{ml}$ of $0.8 \%$ thiobarbituric acid (TBA) solution. Mixture was diluted up to $4 \mathrm{ml}$ with distilled water and heated at $95^{\circ} \mathrm{C}$ for $60 \mathrm{~min}$. After cooling on ice, the samples were extracted with $4 \mathrm{ml}$ of the mixture of $n$ butanol and pyridine $(15: 1, \mathrm{v} / \mathrm{v})$. Centrifugation at 3,000 rpm for $10 \mathrm{~min}$, the organic phase was collected and the absorbance measured at a wavelength of $532 \mathrm{~nm}$. [8]

\section{Superoxide dismutase estimation}

The activity of superoxide dismutase (SOD) was estimated using Misra and Fridovich method. Here, $10 \mu \mathrm{l}$ of sample was added to $970 \mathrm{ml}(0.05 \mathrm{M}, \mathrm{pH} 10.2,0.1 \mathrm{mM}$ EDTA) of sodium carbonate buffer. $20 \mu \mathrm{l}$ of $30 \mathrm{nM}$ Pyrogallol was added to start the reaction. SOD activity was measured at 480nM. [9]

\section{DPA assay for DNA fragmentation}

The diphenylamine (DPA) reaction was performed by the method of Paradones et al. (1993). Perchloric acid $(0.5 \mathrm{M})$ was added to the cell pellets containing uncut DNA (resuspended in $200 \mu$ of hypotonic lysis buffer) and to the other half of the supernatant containing DNA fragments. Then two volumes of a solution consisting of $0.088 \mathrm{M} \mathrm{DPA}, 98 \%(\mathrm{v} / \mathrm{v})$ glacial acetic acid, $1.5 \%(\mathrm{v} / \mathrm{v})$ sulphuric acid, and a $0.5 \%(\mathrm{v} / \mathrm{v})$ concentration of $1.6 \%$ acetaldehyde solution were added. The samples were stored at $4{ }^{\circ} \mathrm{C}$ for $48 \mathrm{~h}$. The reaction was quantified spectrophotometrically at $575 \mathrm{~nm}$. The percentage of fragmentation was calculated as the ratio of DNA in the supernatants to the total DNA. [10]

\section{STATISTICAL ANALYSIS}

All the observations were expressed as mean and standard error of mean. One way ANOVA was used to find out the statistical significance by setting significance at $p<0.05$.

\section{RESULTS}

All the observations were tabulated and graphically represented.

1. Cell morphology - There was significant change in the membrane integrity which lead to cell lysis. It was seen more with higher dose of nicotine compared to control and other groups.

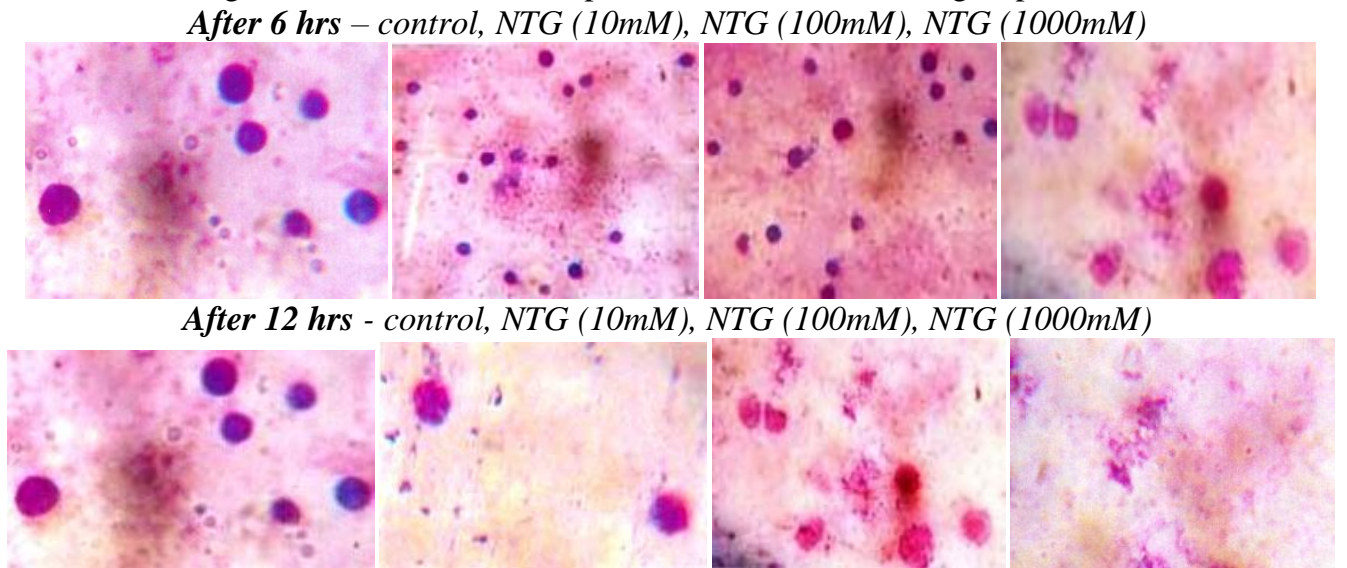

Figure 1. Nicotine induced morphological changes in lymphocytes (at different doses and duration). 
2. Cell viability - The percentage of viable lymphocytes decreased in nicotine treated groups in comparison to control. The maximum toxicity was seen with $1000 \mathrm{mM}$ nicotine treated groups on lymphocyte viability (figure 2).

3. Superoxide anion production -Superoxide generation was increased significantly $(P<0.05)$ at both doses of in vitro nicotine toxicity. While $100 \mathrm{mM}$ nicotine administration showed the maximum superoxide generation (figure 3 ).

Table 1. Lymphocyte viability and superoxide generation after treating with nicotine at various concentrations

\begin{tabular}{|l|l|l|l|l|}
\hline \multirow{2}{*}{ Group } & \multicolumn{2}{|l|}{ \% of viable lymphocytes } & \multicolumn{2}{l|}{ Superoxide Radicals (nmol/min/2X10 } \\
\cline { 2 - 5 } & 6 Hrs. & $\mathbf{1 2}$ Hrs. & 6 Hrs. & 12 Hrs. \\
\hline Control & 96.88 & 93.06 & 0.83 & 0.87 \\
\hline NTG $(10 \mathrm{mM})$ & 85.71 & 80.81 & 1.17 & 2.87 \\
\hline NTG $(100 \mathrm{mM})$ & 79.88 & 65.12 & 1.55 & 4.95 \\
\hline NTG $(1000 \mathrm{mM})$ & 63.33 & 53.35 & 2.86 & 5.03 \\
\hline
\end{tabular}

$\mathrm{n}=6, \mathrm{NTG}-$ Nicotine treated group, ${ }^{*} \mathrm{p}<0.05$

4. Lipid peroxidation (Thiobarbituric acid test)- MDA levels were significantly $(P<0.05)$ increased in 10 and $100 \mathrm{mM}$ nicotine treatment for $12 \mathrm{~h}$ by $81.8 \%$ and $241.57 \%$, respectively, as compared to the control group (table 2).

5. Superoxide dismutase estimation (Misra and Fridovich method) - The SOD activity was significantly $(P<0.05)$ reduced by $33.87 \%$ and $63.79 \%$, respectively due to 10 and $100 \mathrm{mM}$ nicotine treatment in relation to control (table 2$)$.

Table 2.MDA and SOD estimation in various groups.

\begin{tabular}{|l|l|l|l|l|}
\hline \multirow{2}{*}{ Group } & \multicolumn{2}{|l|}{ MDA (nMol/mg of protein) } & \multicolumn{2}{l|}{ SOD (U/min/mg of protein) } \\
\cline { 2 - 5 } & 6 Hrs. & 12 Hrs. & 6 Hrs. & 12 Hrs. \\
\hline Control & 56.09 & 58.09 & 65.92 & 62.81 \\
\hline NTG(10 mM) & 83.88 & 105.61 & 49.26 & 41.53 \\
\hline NTG(100 mM) & 123.46 & 198.42 & 35.11 & 22.74 \\
\hline NTG $(1000 \mathrm{mM})$ & 129.92 & 206.63 & 33.61 & 24.07 \\
\hline
\end{tabular}

$\mathrm{n}=6, \mathrm{MDA}-$ malondialdehyde, SOD - Superoxide dismutase $* \mathrm{p}<0.05$

6. DPA assay for DNA fragmentation (Perandoneset al method) -DNA fragmentation (DPA assay) was measured by spectrophotometric method. $10 \mathrm{mM}$ and $100 \mathrm{mMin}$ vitro nicotine treatment produced the $54.36 \%$ and $86.04 \%$ fragmented DNA, respectively, whereas control group shows the negligible $8.38 \%$ fragmented DNA, which are associated significantly $(P<0.05)$.

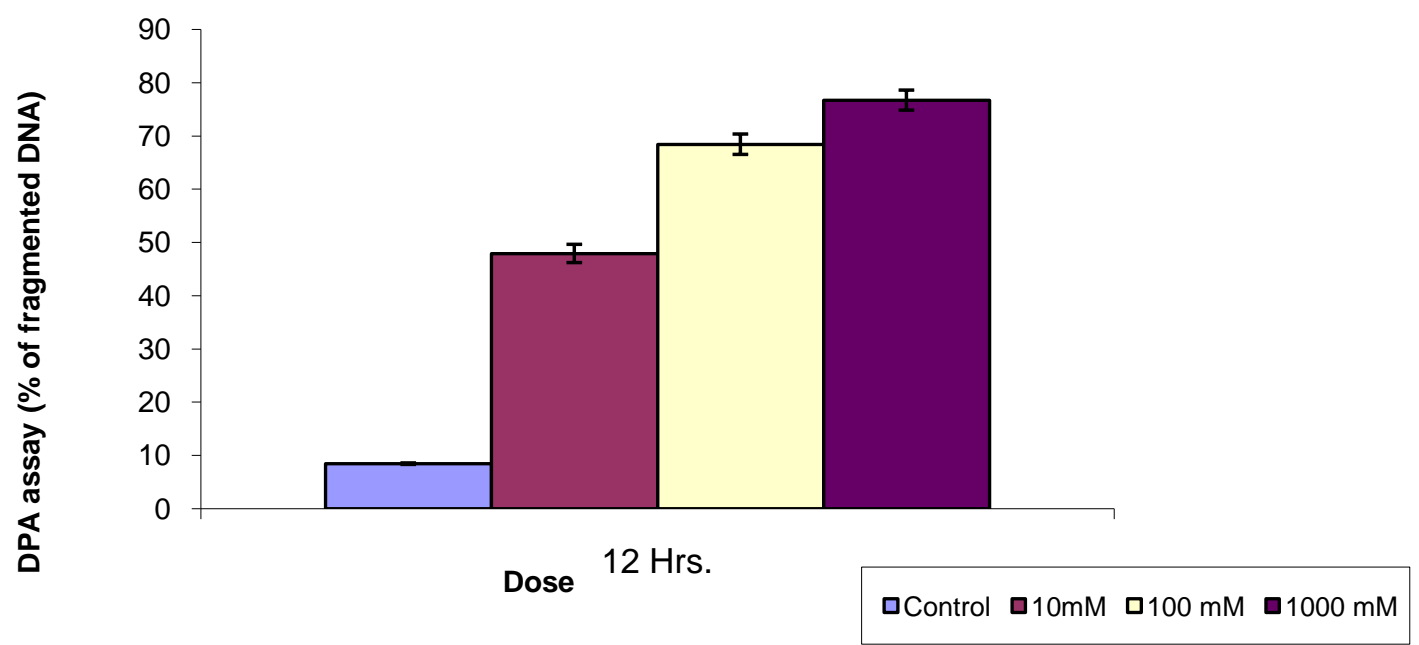

Figure 2. DPA assay for DNA fragmentation in various groups 


\section{DISCUSSION AND CONCLUSION}

Free radical-induced oxidative stress has been implicated in the pathogenesis of a wide variety of clinical disorders caused by nicotine. In the present study, nicotine has been shown to induce superoxide anion $\left(\mathrm{O}_{2}^{-}\right)$generation. A major component of the antioxidant system in mammalian cells consists of three enzymes, namely, superoxide dismutase (SOD), catalase (CAT) and glutathione peroxidase (GPx). [11]

In the present study, the nicotine treated lymphocytes suffered significantly elevated DNA fragmentation and MDA, along with decreased viability of the cells. SOD activity was also decreased significantly with all the doses of nicotine treatment. This decrease in SOD activity apart from direct nicotine toxic effect may also be due to increasing level of lipid peroxidation and protein oxidation products, which may be associated with the DNA fragmentation in lymphocytes.

Peripheral blood lymphocytes are very much susceptible to nicotine toxicity through the increased $\mathrm{O}_{2}^{2-}$ generation, leading to decreased antioxidant status, macromolecules oxidation and DNA fragmentation.

In conclusion, we can infer from our study that, nicotine treatment at different dose and duration induces cellular damage by changing cell membrane integrity which is affected by LP level of lymphocytes. High level of LP may be due to excessive generation of free radicals. With increased LP, the cellular damage is also increased and the viability of lymphocytes will be decreased. The high level of oxidative stress due to nicotine toxicity might be the cause of DNA fragmentation of lymphocytes.

\section{REFERENCES}

[1] Yildiz D, Ercal N and Armstrong D W. Nicotine enantiomers and oxidative stress, Toxicology 1998; 130:155-165.

[2] McAllister-Sistilli GC, Anthony RC, Steve K, Christine AR, Miller AL and Donny EC. Effects of Nicotine on the Hypothalamic-Pituitary-Axis (HPA) and Immune Function. Journal of Psychoneuroendocrinology 1998; 23(2):175-187.

[3] Hudson L and Hay F C. Practical Immunology, Blackwell Scientific Publications, Oxford University Press (1991) pp. 21-22.

[4] Das S, Neogy S, Gautam N and Roy S. In vitro nicotine induced superoxide mediated DNA fragmentation in lymphocytes: Protective role of AndrographispaniculataNees, Journal ofToxicology in Vitro 2009; 23(1): 90-98.

[5] Boveris A. Determination of the production of superoxide radicals and hydrogen peroxide in mitochondria, Methods in Enzymology 1984; 105: 429-435.

[6] O’Brien P J. Superoxide production, Methods in Enzymology1984; 105: 370-378.

[7] Goldstein I M, Cerqueia M, Lond S and Kaplan H B. Evidence that the superoxide generating system of human leukocytes is associated with the cell surface, Journal of Clinical Investigation 1977; 59: 249-254.

[8] Ohkawa H, Ohishi $\mathrm{N}$ and Yagi K. Assay for lipid peroxides in animal tissues by thiobarbituric acid reaction, Analytical Biochemistry 1979; 95: 351-358.

[9] Marklund S and Marklund M. Involvement of superoxide anion radical in autoxidation of pyrogallol and a convenient assay of superoxide dismutase, European Journal of Biochemistry 1974; 47: 469-474.

[10] Paradones C E, Illera VA, Peckham D, Stunz L L, Ashman R F. Regulation of apoptosis in vitro in mature spleen T cell, Journal of Immunology1993; 151: 3521.

[11] Maes M, Galecki P, Chang YS, Berk M. A review on the oxidative and nitrosative stress pathways in major depression and their possible contribution to the (neuro)degenerative processes in that illness, Progress in NeuroPsychopharmacology \&Biol Psychiatry (2010), doi:10.1016/j.pnpbp.2010.05.004. 